\title{
Year 6 Pupils' Language Learning Strategies in Learning English Grammar
}

Thomas Mason Lim, Darrel Wong Lee Sze, Dora Raki, Liza Michelle Lim, Sarina Sani, Harwati Hashim

To Link this Article: http://dx.doi.org/10.6007/IJARBSS/v11-i4/9690

DOI:10.6007/IJARBSS/v11-i4/9690

Received: 15 February 2021, Revised: 20 March 2021, Accepted: 10 April 2021

Published Online: 30 April 2021

In-Text Citation: (Lim et al., 2021)

To Cite this Article: Lim, T. M., Sze, D. W. L., Raki, D., Lim, L. M., Sani, S., \& Hashim, H. (2021). Year 6 Pupils' Language Learning Strategies in Learning English Grammar. International Journal of Academic Research in Business and Social Sciences, 11(4), 1196-1209.

Copyright: (c) 2021 The Author(s)

Published by Human Resource Management Academic Research Society (www.hrmars.com)

This article is published under the Creative Commons Attribution (CC BY 4.0) license. Anyone may reproduce, distribute, translate and create derivative works of this article (for both commercial and non-commercial purposes), subject to full attribution to the original publication and authors. The full terms of this license may be seen at: http://creativecommons.org/licences/by/4.0/legalcode

Vol. 11, No. 4, 2021, Pg. 1196 - 1209

Full Terms \& Conditions of access and use can be found at http://hrmars.com/index.php/pages/detail/publication-ethics 


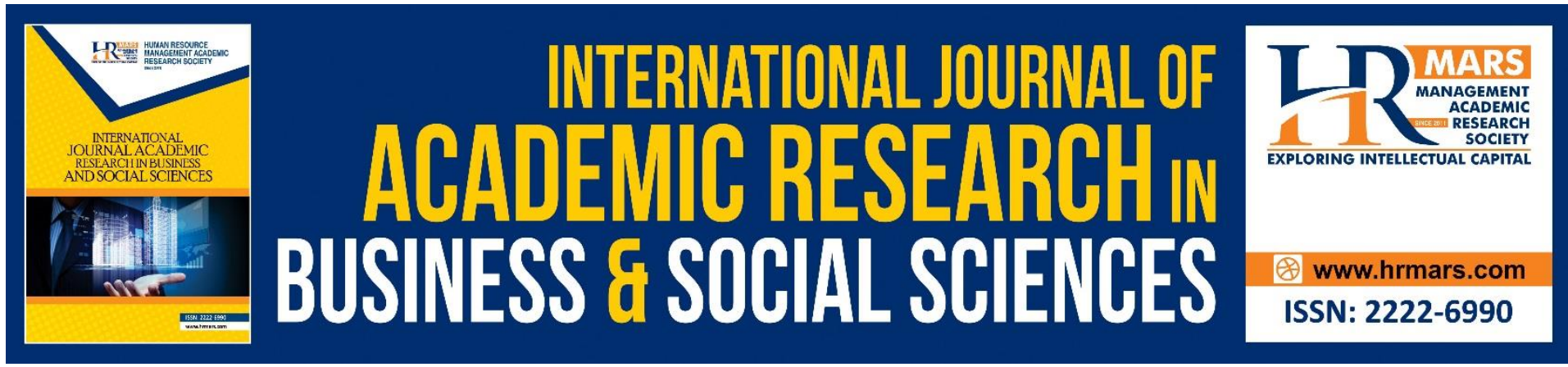

\title{
Year 6 Pupils' Language Learning Strategies in Learning English Grammar
}

\author{
Thomas Mason Lim, Darrel Wong Lee Sze, Dora Raki, Liza \\ Michelle Lim, Sarina Sani, Harwati Hashim \\ Faculty of Education, Universiti Kebangsaan Malaysia \\ Email: tommylim5353@yahoo.com
}

\begin{abstract}
Language rules, otherwise known as grammar, play an important role in determining the accuracy of a message delivered verbally and non-verbally. Some learners gain new language easily while others may face difficulties. The different pace in their language acquisition may be attributed to the different learning strategies that they adopted. Past research has revealed how learners acquired their grammar knowledge, but little has been related to specific Language Learning Strategies (LLS). Thus, in this study, the Strategy Inventory for Language Learning (SILL) Version 7.0 by Oxford (1990) was utilized to identify, analyze, and explore the LLS commonly used by the learners in the Year 6 class of a primary school in Sarawak in learning English grammar. A survey consisting of 30 questions with a Likert scale of 1 to 5 was administered to 30 pupils who were selected through purposive sampling. The pupils were all living in suburban areas and that put them in a homogenous group. The data was obtained through in-class questionnaires and SPSS Version 25 was used to analyze the mean of each strategy. The results of the study uncovered that cognitive strategy is the most used LLS while memory strategy is the least used LLS by the Year 6 pupils of a primary school in Sarawak in learning English grammar.
\end{abstract}

Keywords: Language Learning Strategies (LLS), Grammar, Suburban Areas, Strategy Inventory for Language Learning (SILL)

\section{Introduction}

Grammar is a crucial component in all language skills mainly reading, writing, speaking, and listening. To ensure meaningful sentences are well-conveyed, language rules or grammar has a paramount role in determining the accuracy of a message delivered verbally and nonverbally. In English language learning, some learners acquire more rapidly and effectively depending on the differences of individuals, while others may need to battle and gain moderate headway (Vance, 1999). One of the elements crediting to the individual differences is the ways and strategies of learning. Oxford (1990) defines these strategies as the actions implemented purposely by the learners to ensure the process of learning is smoother, simpler, more fun elements, more learner-centered, more impactful, and more applicable to the real world. On top of that, Rubin (1975) also agrees that learning strategies do assist learners in some ways to make English learning occur effectively. Language Learning 
Strategies (LLS) has been widely recognized as an extremely powerful learning tool since the $19^{\text {th }}$ century (O'Malley \& Chamot, 1990).

In the past ESL teaching and learning process in the classroom, grammar components were often acquired through memorizing the concepts, repetitive drilling, consistent writing practices and even using pictures as stimulus to ensure learners were on the right track of the grammatical items that they were learning. In addition, Wright (2011) asserted through construction, learners tend to understand better about the significance of words. Hence, they manage to apply certain words as well as word classes in a correct and relevant manner when communication occurs in speech or writing. Taylor (2020) asserted drilling is an effective learning of grammar as the first practice stage for learners as it provides an extremely controlled practice of using the target language. A research done by Bezuglova, llyasova and Beisembayeva (2019) stated that an inductive approach to English grammar teaching which comprises the processes of noticing, understanding, forming, and using can help learners to bring their knowledge and show how it can be applied in the classroom.

With the purpose of developing effective grammar learning, the learners need to recognize which strategies are the most effective for them. Therefore, to ensure successful learning, the language learning strategies can be properly discovered as there are various strategies, methods, and approaches to work with the brain autonomy in building chains of grammatical components among the learners. Basically, a strategy of learning is about how one organizes and applies a certain set of skills to adopt and adapt the content or complete other tasks in a more effective and efficient manner despite not being in educational settings (Schumaker \& Deshler, 1992). To be precise, Oxford (1990) classified the theory into two strategies, whereby the first is direct strategies and latter indirect strategies. These strategies comprise of cognitive, metacognitive, memory, compensation, affective, and social learning strategies. The Oxford (1990) strategies can be effectively adopted by rather than adopting one particular strategy (O'Malley et al., 1985). Oxford's taxonomy of language learning strategies (LLS) is indicated below in Table 1.

Table 1: Summary of Language Learning Strategies in Grammar Acquisition

\begin{tabular}{|c|c|c|}
\hline $\begin{array}{c}\text { Classes of Language Learning } \\
\text { Strategies }\end{array}$ & $\begin{array}{l}\text { Categories of Language } \\
\text { Learning Strategies }\end{array}$ & Types of Learning Strategies \\
\hline \multirow{3}{*}{ Direct strategies } & Memory & $\begin{array}{l}\text { - } \quad \text { creating linkages mentally } \\
\text { - } \quad \text { relating grammar components to sounds and visuals } \\
\text { - } \quad \text { taking actions }\end{array}$ \\
\hline & Cognitive & $\begin{array}{l}\text { - } \quad \text { regular grammar practice } \\
\text { - } \quad \text { obtaining and redirecting messages } \\
\text { - } \quad \text { probing and reasoning } \\
\end{array}$ \\
\hline & Compensation & $\begin{array}{l}\text { - } \quad \text { giving answer without adequate hints } \\
\text { - } \quad \text { problem solving }\end{array}$ \\
\hline \multirow{3}{*}{ Indirect strategies } & Metacognitive & $\begin{array}{ll} & \text { centralize the learning } \\
\text { - } & \text { finding and solving problems collaboratively } \\
\text { - } & \text { self-evaluated learning }\end{array}$ \\
\hline & Social & $\begin{array}{l}\text { - } \\
\text { - } \\
\text { - } \\
\text { collaborating questions } \\
\text { empathizing with others } \\
\end{array}$ \\
\hline & Affective & $\begin{array}{ll}\text { - } & \text { decreasing anxiety } \\
\text { - } & \text { self-managing personality factors } \\
\text { - } & \text { self-assessment on personal emotion and feeling }\end{array}$ \\
\hline
\end{tabular}


Undeniably, language learning strategies (LLS) have been always significant in facilitating the learners to learn independently and an aspect of induction for the educators in their teaching and learning process. Thus, in this research, the Strategy Inventory for Language Learning Version 7.0 by Oxford (1990) was utilized to identify, analyze, and explore the LLS commonly used by the learners in the Year 6 class of a primary school in Sarawak in learning English grammar.

English Language plays a significant role globally as it is a language of trade, economy and also communication. In order to achieve good proficiency of the language, having a good foundation of grammar is among the essential elements to combine all the word classes in correct tenses and structures to form meaningful sentences. Ellis (2006) asserted that grammar learning is able to effectively complete learners with a solid foundation which aids them in building new knowledge to make use of the language well. Even though to some extent, some researchers might insist that vocabulary is a more impactful factor in learning a language. However, communication is meant to be broken down if accuracy is not magnified in the language despite a learner is rich with vocabulary. Information can be misinterpreted in written and oral communication due to the poor use of grammar (Petrova, 2017).

Additionally, learners with poor use of grammar will also face challenges in expressing themselves in spoken English. Crystal (2012) asserted that the learners' awareness towards the functions of grammar is proportional to the monitoring level of the meaning and effectiveness in using the language. Learners who do not know the ways in using grammar, face a high chance of possibility that they might gradually be demotivated in learning English. Generally, the lack of repertoire in English has developed a decline in interests among learners in acquiring English as a communicative language. This is contributed by the challenges and difficulties they face in learning the rules of language. Consequently, most second language or foreign language learners are not interested in learning English and despite their presence in the class, their motivation and eagerness in learning English appropriately is extremely low. Therefore, learning English grammar must inculcate several learning strategies to cater the learners' needs which may remotivate and stir their interests in learning the language again.

On top of that, learners who often struggle in learning the language are believed to face difficulties which they themselves are unaware of. They might overlook the useful hints and sources which they can adapt and adopt to improve their learning of the language. There are several strategies that are recommended for learners when they are learning English. These include the strategies from the aspect of cognitive, memory, compensation, metacognitive, affective, and social. Learners need to look for the most appropriate strategies that could help them in learning the language. Appropriate learning strategies of grammar would impact the learning positively. Hence, in this research, the application of language learning strategies (LLS) by the Year 6 pupils of a primary school in Sarawak was investigated. The researchers hope the findings of this study can assist the weaker learners to adopt the language learning strategies (LLS) practiced by the Year 6 pupils to improve their learning as a preparation for them to sit for the UPSR public examination.

\section{Research Objectives}

- To identify the most used language learning strategy among the Year 6 pupils of a primary school in Sarawak in learning English grammar. 
- To identify the least used language learning strategy among the Year 6 pupils of a primary school in Sarawak in learning English grammar.

\section{Research Questions}

- What is the most used language learning strategy among the Year 6 pupils of a primary school in Sarawak in learning English grammar?

- What is the least used language learning strategy among the Year 6 pupils of a primary school in Sarawak in learning English grammar?

\section{Literature Review \\ English language Grammar}

Since the beginning of time, English has always been an important subject in the education system in Malaysia. The language is taught in schools, be it national, national-type, or international schools. In Malaysia, English is perceived as one of the most important languages. Thus, this makes English the second language in Malaysia, after the Malay language which is the national language of the country. English is taught as a second language (ESL) since kindergarten till secondary school. With an average of only 5 hours of learning the language weekly, English is still a challenge to many learners, regardless of age and gender. To those who do not use the language outside of the classroom, the challenge is even bigger due to lack of practice. To make the situation worse, the English curriculum is constantly changing in accordance with the different needs and demands, thus making it hard for learners to adapt quickly (Rahman, Sazali \& Veloo, 2019). It is safe to say that due to this, the level of proficiency among learners is still at a worrying level. Research conducted before had pointed out that learners face difficulties in being proficient in the language because of their lack of knowledge of the linguistic system, otherwise known as the grammar rules (Salleh, Biase \& Ramlan, 2020). Learners are not able to recognize and produce the words correctly, and therefore, their proficiency levels are relatively low.

Realizing the situation, the Ministry of Education of Malaysia has worked with various stakeholders in the education system to help combat this dire situation. Drastic measures such as the implementation of the Common European Framework of Reference (CEFR) was carried out to revamp the education system so that the learners can improve their level of proficiency to be at that of foreign countries (Yasin \& Yamat, 2021). With the implementation of the CEFR, positive results can be seen as learners are now given a clearer guideline and goal to achieve based on the different bands in the framework. However, the issue of imposing the foreign curriculum without considering the local contexts was brought to light. Such an issue has dampened the effort to help improve the learners' language proficiency. This clearly shows that the education system in Malaysia is facing endless struggles in improving learners' grammar abilities. Xianzhi (2020) argued that grammar is not only found to be boring, but it has also fallen in disfavor from learners due to its rules which are more often than not, difficult, and tedious to remember.

Learners should understand that grammar is the basis of the language. Without proper command, users of the language will find difficulties in both verbal and written communication. While studying a language, vocabulary alone cannot help to account for 
communicative success (Chai et al., 2020). Grammar needs to be incorporated in one way or another. Grammar is in fact the key to knowing a language as it is the system that helps to accommodate real communicative use of the English language. It is also worth noting that English language grammar has several different kinds, and this is the reason why learning it is often difficult among learners. For the purpose of this study, grammar knowledge is referred to as the basic rules used in daily communication, both recognition and production. In addition, grammar rules are also referred to as the main construct in this research, in which the research participants will focus on while answering the questionnaire questions given.

\section{Language Learning Strategies (LLS)}

As everybody is born different, it is only right that everything we do is not necessarily the same as others. It is almost, if not totally, impossible to be exactly the same as another person. This is also the same when it comes to language learning. The rate or speed someone learns the language depends on various aspects such as environment, understanding, and level of motivation (Amir, 2018). A clear example would be the learning of the English language. A native speaker who has been using the language at home since young would have no problem in articulating the words. As asserted by Griffiths and Soruç (2020), this is the opposite for non-native speakers due to the absence of an English-speaking environment when they were growing up. Due to this, the amount of knowledge in the language is clearly different individually. This is also the reason why there are different language learning strategies which are commonly practiced.

The number of research done on language learning strategies (LLS) has increased exponentially over the years, especially on how learners process and handle new information. LLS can be viewed from different angles and according to Teng and Zhang (2019), attitude, motivation, age, sex, learning styles, and capabilities are all main factors which affect every person's LLS. Oxford (1990) categorized language learning strategies into two different types; mainly direct strategies and indirect strategies. Direct strategies comprise of memory strategy, cognitive strategy, and compensation strategy. Meanwhile, indirect strategies include metacognitive strategy, affective strategy, and social strategy. Direct strategies involve the specific use of language while indirect strategies do not involve using the language (Oxford 1990).

As mentioned earlier, LLS is influenced by different factors, depending on the respective individuals. Rubin (1975) asserted that good language learners are willing to learn and are accurate in guessing. In addition to that, they are also able to communicate well with others and learn from the communication. They are also willing to make mistakes through practice and every opportunity which comes upon them will be taken advantage of to learn and improve. However, this is not the case for all learners. Learners learn differently based on their own learning styles and strategies. It is imperative for teachers everywhere to be aware of this and understand that there is no one learning strategy that is suitable for all types of learners. It is also highly recommended for teachers to help path the way for learners to seek and discover the best language learning strategy for their learners.

\section{Strategy Inventory for Language Learning (SILL)}

In 1990, Rebecca Oxford developed the Strategy Inventory for Language Learning (SILL). It was developed to assess the frequency of learning strategies used by learners. SILL consists of a 
five-point Likert-scale questionnaire. In the questionnaire, there are fifty questions which cover the six types of learning strategies, mainly the memory strategy, cognitive strategy, compensation strategy, metacognitive strategy, affective strategy, and social strategy. Usually, researchers would assign a score to each of the Likert scale items (1 to 5). Therefore, the common range of the scores in the SILL is between 50 to 250. A higher score indicates higher level of efficiency in language learning and vice versa. SILL is deemed highly reliable due to its Cronbach alpha which is above 0.90 .

\section{Methodology}

\section{Research Design}

The objective of this research is to classify the most widely and least used LLS in uptown areas among Year 6 students. A computational analysis design for data collection was introduced. In order to gather findings, a survey study consisting of 30 questions of Likert scale was used. Survey analysis was used to obtain information within a broad group from a single survey. The research utilized Oxford's (1990) edition 7.0 Strategy Inventory for Language Learning (SILL), which is the most reliable tools to identify language learning strategies (LLS).

\section{Research Instrument}

The research utilized Strategy Inventory for Language Learning (SILL) version 7.0 to gather information on desire objectives. SILL is a survey tool constructed by Oxford (1990). Lee (2010) stated that SILL is a highly comprehensive and thorough tool to investigate learning strategy among the learners. This is further advocated by Habók and Magyar (2018) where they mentioned that this instrument is a suitable taxonomy to be used taxonomy in assessing the strategy used by ESL/EFL learners. This version used 5 Likert-scale $(1,2,3,4,5)$ for learners to answer the questions. The students evaluated themselves using this instrument and reflect on the extent at which they use various language strategies. The questionnaire consists of 30 questions which are divided into 6 parts:

The survey comprises 30 questions which were split into six segments:

\begin{tabular}{cc}
\multicolumn{2}{c}{ Table 2: Description for each part of the questionnaire. } \\
\hline Part & Description \\
\hline Part A: Question 1-5 & Memory Strategy \\
Part B: Question 6-10 & Cognitive Strategy \\
Part C: Question 11-15 & Compensation Strategy \\
Part D: Question 16-20 & Metacognitive Strategy \\
Part E: Question 21-25 & Affective Strategy \\
Part F: Question 26-30 & Social Strategy \\
\hline
\end{tabular}

All the statements were rated on a Likert scale of 1-5, to indicate the degree of which the participants agree or disagree to any statements based on their experience on the LLS. Each number of the Likert scale was defined as follows: 
Table 3: Likert scale description for each Language Learning Strategy statement

\begin{tabular}{cc}
\hline Scale & Description \\
\hline 2 & Never or almost never true of me \\
3 & Usually not true of me \\
4 & Somewhat true of me \\
5 & Ulways or ally true of me \\
\end{tabular}

\section{Research Samples}

The researchers employed purposive sampling to conduct the study. Apart from that, the learners were all living in suburban areas and that put them in a homogenous group. With these samples, the data will have good reliability due to its characteristics. In order to classify the linguistic learning techniques used in uptown regions, the study is composed of thirty students.

\section{Data Collection Method}

The research was conducted using quantitative investigation and the results was in quantitative data. The data was obtained by means of the in-class questionnaire. The questionnaire was circulated by the researchers during the English language period. The data was gathered directly after the participants have responded to the questionnaire.

\section{Data Analysis Method}

A descriptive study was carried out for the results of the most and least used language learning strategy by the uptown students. In order to facilitate the aim of the analysis, the mean score of each strategy was evaluated. The researchers obtained a database using SPSS Version 25 to analyze the mean of each strategy.

\section{Findings}

\section{Research Question 1}

What is the most used language learning strategy among the Year 6 pupils of a primary school in Sarawak in learning English grammar?

The mean for each of the six language learning methods is shown in Table 4. The most common strategy used by language learners in the suburban area, according to the survey questionnaire results, is cognitive strategy, with a mean score of 3.446. It is believed that due to the practicality of the strategy, this strategy has been ranked as the most used language learning strategy. Corresponding to the table, the language learning strategy often employed by the students begins with cognitive, social, compensation, metacognitive, affective, and in the last ranking is the memory strategy. Cognitive techniques were assessed as the most common strategies among the students because they are adolescent learners who are able to process knowledge thoroughly, transmit, and relate knowledge to additional contexts, improved and well-preserved learning. 
Table 4: Language Learning Strategy with mean score

\begin{tabular}{ccc}
\hline No. & Learning Language Strategies & Mean \\
\hline 1 & Memory & 2.774 \\
2 & Cognitive & 3.446 \\
3 & Compensation & 3.386 \\
4 & Metacognitive & 3.354 \\
5 & Affective & 2.908 \\
6 & Social & 3.392 \\
\hline
\end{tabular}

Table 5 indicates the mean score for each question in the cognitive strategy section which ranked as the most popular strategy employed by the students. The cognitive survey questionnaire includes the following questions: (1) I say or write new English words many times, (2) I try to communicate like native English speakers, (3) I practice the sounds of English, (4) I use the English words I know in various contexts, and (5) I watch English Language TV shows or go to movies spoken in English. Each query received a mean score of 3.20, 3.93, $3.50,2.97$, and 3.63. According to the findings, students in this suburban area used cognitive strategy as their language learning strategy in language acquisition. Table 5 indicates the mean for each particular approach that the students chose.

Table 5: Mean score for cognitive strategy

\begin{tabular}{cccc}
\hline Language Learning Strategies & & \multicolumn{1}{c}{ Specific Strategies } & Mean \\
\hline & 1. & I say or write new English words several times. & 3.20 \\
& 2. & I try to talk like native English speakers. & 3.93 \\
Cognitive & 3. & I practise the sound of English. & 3.50 \\
& 4. & I use the English words I know in different ways. & 2.97 \\
& 5. & I watch English language TV shows spoken in English or go to movies & 3.63 \\
& & &
\end{tabular}

\section{Research Question 2}

What is the least used language learning strategy among the Year 6 pupils of a primary school in Sarawak in learning English grammar?

Table 6 shows the mean scores of the use of memory strategy by language learners in the suburban area. The results revealed that memory strategy is the least used strategy. Specific learning strategies used in memory strategy are (1) I use new English words so I can remember them, which scores a mean of 2.20; (2) I connect the sound of a new English word and an image or picture of the word to help remember the word, with a mean of 3.07 ; (3) I remember a new English word by making a mental picture of a situation in which the word might be used, scoring a mean of 3.20; (4) I use rhymes to remember new English words, and (5) I use flashcards to remember new English words, which scored a mean of 2.57 and 2.83 respectively. 
Table 6: Mean score for memory strategy

\begin{tabular}{llr}
\hline $\begin{array}{c}\text { Language Learning } \\
\text { Strategies }\end{array}$ & \multicolumn{1}{c}{ Specific Strategies } & Mean \\
\hline & $\begin{array}{l}\text { 1. I use new English words so I can remember them. } \\
\text { 2. I connect the sound of a new English word and an image or picture of the word to } \\
\text { help remember the word. } \\
\text { Memory }\end{array}$ & 3.07 \\
& $\begin{array}{l}\text { the I remember a new English word by making a mental picture of a situation in which } \\
\text { 4. I use rhymes to remember new English words. }\end{array}$ & 3.20 \\
& 5. I use flashcards to remember new English words. & 2.57 \\
& & 2.83 \\
\hline
\end{tabular}

\section{Discussion}

\section{Research Question 1}

What is the most used language learning strategy among the Year 6 pupils of a primary school in Sarawak in learning English grammar?

The findings have revealed that cognitive strategies are by far the most widely employed language strategies in understanding English grammar. As stated above, cognitive strategies encompassed of the specific strategies as follows, (1) I say or write new English word several times, (2) I try to talk like native English speakers, (3) I practise the sound of English, (4) I use the English words I know in different ways and, (5) I watch English language TV shows spoken in English or go to movies spoken in English. The language learners have a proclivity for using cognitive strategies in learning English grammar as it involves deliberate manipulation of the language for improving learning. Di Carlo (2017) defined cognitive strategies as those actions that learners adopt in a conscious (or potentially conscious), relatively controlled and intentional manner, to optimise assimilation, internalisation, construction, consolidation and transference of knowledge and language skills. The strategies improve a learner's ability to process information more deeply, transfer and apply information to new situations, and result in enhanced and better-retained learning (Winn, 2019).

Cognitive strategies in language learning are direct strategies and are the most popular strategies among the learners in learning English grammar based on the findings. The specific strategies that are most popular are (2) I try to talk like native English speakers, with the mean score of 3.93 and (5) I watch English language TV shows spoken in English or go to movies spoken in English, with a mean score of 3.63. These have shown that the learners prefer to impersonate the way the native speakers speak in order to learn English grammar. They might find it easier to imitate the sentence structure spoken by native speakers and apply the language to another different but similar situations. Other than that, they prefer learning the language by watching English TV shows and movies. This is related to how the learners listen to English words and has imagery from the movies or shows to accompany the English words to make them understand the language better.

In cognitive language learning strategies, learners are aware of their learning process. Learners benefit from direct strategies in learning English grammar because they aid in the storage and retrieval of information (Salleh, Biase \& Ramlan, 2020). Even when there the learners do not fully understood the grammar rules, these strategies assist learners in producing the language. They also assist in learning and using the new language. The most crucial element in the strategies is practising which can be accomplished through repetition, working with sound, writing and the use of pattern (Rahman, Sazali \& Veloo, 2019). The 
example of a learner who uses cognitive learning strategies is practicing with the words that have the sound of the letters ough. The words like cough, rough, plough, and dough are all spelled with the letters ough but they each sounds dissimilar. To be able to comprehend the words' pronunciation well, the learners shall create personal phonetic spelling: kof, ruff, plau, and dow.

From this study, we could assure that the learners gauge themselves with learning English grammar and encourage direct and conscious learning for the learners using the strategies. The implications of cognitive strategies have opened the eyes of many language learners to the importance of learning a new language. The fact that cognitive strategies are the most used by the learners suggests that audio and visual teaching materials may be effective tools for stimulating learners at learning English grammar. This suggests that the teachers should make use of this information to create lessons which encourages the use of cognitive strategies.

\section{Research Question 2}

What is the least used language learning strategy among the Year 6 pupils of a primary school in Sarawak in learning English grammar?

The findings indicated that the strategies that are being used the least in learning English grammar are memory strategies. As mentioned above, memory strategies encompassed of the specific strategies as follows, (1) I use new English words so I can remember them, (2) I connect the sound of a new English word and an image or picture of the word to help remember the word, (3) I remember a new English word by making a mental picture of a situation in which the word might be used, (4) I use rhymes to remember new English words, and (5) I use flashcards to remember new English words. The results clearly revealed that the learners are less likely to use memory strategies in learning English grammar which has the mean score of only 2.774. Oxford (1990) stated that memory strategies are direct strategies that involve the mental processes for storing new information in the memory and for retrieving them when needed. These strategies entail four sets: creating mental linkages, applying images and sounds, reviewing well, and employing action.

Direct language learning strategies support and manage learners' language learning directly involving the target language (Oxford, 1990). In their learning, they use techniques such as repetition, organising new language, summarising meaning, guessing meaning from context, and using imagery for memorisation. The reason behind the results is probably because the learners are Year 6 students and they may find learning using imagery tools like flashcards or rhymes are not suitable for them. Other than that, it is quite disheartening to find out that the strategies involving summarising are not likely to be used by the learners. However, one must admit that summarising is a time-consuming practise that necessitates complex mental processes, so learners are likely to avoid it. Samida (2013) summarised that memory strategies are based on simple principles like laying things out in order, making association, and reviewing. When a student is having difficulty studying, these ideas are used. Learners should be able to associate words and phrases with visual images that they can save and retrieve for the purpose of communication. The learners should be made aware that using visual images to associate words and phrases to sound, motion, or touch is a great help for learning English grammar (Salleh, Biase \& Ramlan, 2020). Memory strategies are most often used at the starting of a language learning process. The year 6 students most probably think that it is more suitable for younger learners and as they grow older, memory strategies are being applied less. It is not that usage stops; it is just that people are less conscious of it. 
From this study, we can see that such great strategies like memory strategies are not being taken seriously by the learners. Although it seems simple, but the strategies are very useful for the learners. The lack of using memory strategies implies that the learners should be told and taught how memory strategies can be beneficial for their learning of English grammar. Teachers play a crucial role to ensure that learners can benefit to the maximum from any preferred and suitable language learning strategies.

\section{Conclusion}

Grammar is a vital element in language learning because it ensures that sentences are wellconveyed and delivered accurately. Teachers often teach grammar through concept memorization, repetitive drilling, consistent writing practices and using pictures as stimulus. However, language learning does not only rely on teachers, but learners as well must be able to identify which strategies are the most effective for them so that it would impact them positively. Hence, teachers must discover which language learning strategies are used the most by learners when building grammatical knowledge. This study investigated the most used and least used language learning strategies by pupils in a primary school in Sarawak in learning English grammar. The results implied that cognitive strategy is the most used LLS while memory strategy is the least used LLS. Other than that, this study also proved that the learners are aware of their learning process. Although the learners have inadequate grammar knowledge, the cognitive strategy that they adopted in their learning strategy helped them to produce language through continuous practice and repetition. These learners are relentless and therefore, teachers must take advantage by giving lots of practices and drills to them. In this order, the learners will be able to learn grammar more effectively and consequently, help them to achieve learning objectives. Memory strategy is no longer suitable for them because they are adolescent learners. They do not think that the use of flashcards or rhymes in grammar learning is suitable for them and so they do not take it seriously. Thus, teachers should use this information to create lessons and utilize tools such as audio and visual teaching materials that can stimulate learners in using cognitive strategies successfully. Although the present study successfully indicated the most used and least used language learning strategy used by pupils in suburban areas, it did not explain in detail the factors influencing the use of the specific LLS. Future research should focus on these factors to better comprehend the language learning strategies adopted by suburban pupils in context and beyond.

This study serves as a guide for educators worldwide, that although there are various learning strategies available these days, not all are suitable for every learner. It is important for teachers to help their students identify the best learning strategy which suits them best. This study has also confirmed that in the teaching and learning of the English language, various strategies can be applied, not only to primary school pupils, but all learners from all levels of education. To sum up, it is safe to say that this study is a new window to the topic of language learning strategies and will definitely be of great help for teachers and learners in the future, especially in the teaching and learning of the English language.

\section{References}

Amir, M. (2018). Language Learning Strategies Used by Junior High School EFL Learners. Language and Language Teaching Journal, 21(1), 94-103.

Bezuglova, O. A., Ilyasova, L. G., \& Beisembayeva, Z. (2019). Teaching grammar to bilingual learners. International Journal of Higher Education, 8(7), $44-49$. 
Chai, K., Jong, B., Dison, M., Thomas, S. A., Yunus, M., \& Suliman, A. (2020). Enhancing Malaysian Primary Pupils' Vocabulary Skills using Pocable Game and Pear Deck. International Journal of Learning, Teaching and Educational Research, 19(6), 145-160.

Crystal, D. (2012). English as a Global Language. New York: Cambridge University Press.

Di Carlo, S. (2017). Understanding Cognitive Language Learning Strategies. International Journal of Applied Linguistics and English Literature, 6(2), 114-126. doi:http://dx.doi.org/10.7575/aiac.ijalel.v.6n.2p.114

Ellis, R. (2006). Current issues in the teaching of grammar: an SLA perspective. TESOL Quarterly, 40(1), 83-107.

Griffiths, C., \& Soruç, A. (2020). Language Learning Strategies. In Individual Differences in Language Learning (pp. 113-129). Palgrave Macmillan, Cham. doi:https://doi.org/10.1007/978-3-030-52900-0_8

Habok, A., \& Magyar, A. (2018). The Effect of Language Learning Strategies on Proficiency, Attitudes and School Achievement. Frontiers in Psychology. 8:1-8 DOI:10.3389/fpsyg.2017.02358

Lee C.K. (2010). An overview of Language Learning Strategies. Annual Review of Education, Communication, and Language Sciences 7:132-152

O’Malley, J. M., Chamot, A., Stewner-Manzanares, G., Küpper, L., \& Russo, P. R. (1985). Learning strategies used by beginning and intermediate ESL students. Language Learning, 35(1), 21-46.

O'Malley, J. M., \& Chamot, A. U. (1990). Learning Strategies in Second Language Acquisition. New York: Cambridge University Press.

Oxford, R. L. (1990). Language Learning Strategies: What Every Teacher Should Know. C a I i forni a: N e w b u $r$ y $\mathrm{H}$ o u s e P u b I is he $r$.

Petrova, K. (2017). Problems caused by incorrect grammar. wehttps://medium.com/@petrovakate819/problems-caused-by-incorrect-grammar10209fec86bd [31 March 2021].

Rubin, J. (1975). What the "Good Language Learner" can teach us. TESOL Quarterly 9(1), 415

1

Rahman, F. A., Sazali, N. H., \& Veloo, A. (2019). Empowering Children Through Circle Time: An Intervention to Promote Language Interaction in Primary ESL Classroom in Malaysia. Practitioner Research, 1(July), $263-287$.

Salleh, R. T., Biase, B. D., \& Ramlan, W. N. (2020). The Acquisition of English Grammar Among Malay-English Bilingual Primary School Children. GEMA Online Journal of Language Studies, 20(4), 166-185.

Samida, D. K. (2013). Language Learning Strategies. https://www.studymode.com/essays/Language-Learning-Strategies-1506481.html

Schumaker, J. B., \& Deshler, D. D. (1992). Validation Of Learning Strategy Interventions For Students With LD: Results Of A Programmatic Research Effort. In Y. L. Wong (Ed.), Contemporary Intervention Research in Learning Disabilities: An International Perspective. New York: Springer-Verlag.

Taylor, K. (2020). Teaching techniques: 6 steps to effective drilling. https://www.eslbase.com/tefl-a-

z/drilling [29 March 2021].

Teng, L. S., \& Zhang, L. J. (2019). Empowering learners in the second/foreign language classroom: Can self-regulated learning strategies-based writing instruction make a difference? Journal of Second Language Writing, 48, 1-16. 
Vance, S. J. (1999). Language learning strategies: Is there a best way to teach them? https://files.eric.ed.gov/fulltext/ED438716.pdf [30 March 2021].

Winn, A. S., DelSignore, L., Marcus, C., Chiel, L., Freiman, E., Stafford, D., \& Newman, L. (2019). Applying Cognitive Learning Strategies to Enhance Learning and Retention in Clinical Teaching Settings. MedEdPORTAL : the journal of teaching and learning resources, 15, 10850. https://doi.org/10.15766/mep_2374-8265.10850

Wright, K. W. (2011). Meaningful grammar. https://thestar.com.my/news/education/2011/12/11/meaningful- grammar March 2021].

Xianzhi, T. (2020). Research on Improving Teaching Efficiency in Class of English Grammar in China Based on Information Technology. 2020 3rd International Conference on Education and Management with Information Technology, (pp. 74-78).

Yasin, N., \& Yamat, H. (2020). Factors Influencing ESL Primary School Teacher's Readiness in Implementing CEFR-aligned Curriculum. International Journal of English Language Studies, 3(2), 44-51. 